REFLEKSI HUKUM

Jurnal Ilmu Hukum
p-ISSN 2541-4984 | e-ISSN 2541-5417

Volume 2 Nomor 2, April 2018, Halaman 139 - 152

DOI: https://doi.org/10.24246/jrh.2018.v2.i2.p139-152

Open access at: http://ejournal.uksw.edu/refleksihukum

Penerbit: Fakultas Hukum Universitas Kristen Satya Wacana

\title{
ASAS PRESUMPTIO IUSTAE CAUSA DALAM KTUN: PENUNDAAN PELAKSANAAN KTUN OLEH HAKIM PERADILAN UMUM
}

\author{
Vincent Suriadinata \\ Pascasarjana Fakultas Hukum Universitas Indonesia \\ Korespodensi: vincent.suriadinata@ui.ac.id
}

\begin{abstract}
Abstrak
Salah satu prinsip penting dalam hukum administrasi negara adalah asas Presumptio Iustae Causa yang menyatakan bahwa setiap keputusan tata usaha negara (KTUN) yang dikeluarkan harus dianggap benar menurut hukum, karenanya dapat dilaksanakan lebih dahulu selama belum dibuktikan sebaliknya dan dinyatakan oleh hakim administrasi sebagai keputusan yang bersifat melawan hukum. Secara tegas dinyatakan bahwa pihak yang berwenang untuk menyatakan penundaan pelaksanaan atau sah tidaknya suatu KTUN adalah hakim administrasi. Menjadi sebuah persoalan hukum manakala dalam putusan perkara nomor 53/Pdt.SusHKI/Cipta/2017/PN Jkt.Pst dinyatakan bahwa SK Menkumham yang menjadi legal standing penggugat harus diuji keabsahannya terlebih dahulu sehingga mengakibatkan gugatan tidak dapat diterima. Hakim dalam perkara ini telah melampaui kewenangannya karena hakim pada peradilan umum tidak memiliki kewenangan untuk menilai sah tidaknya sebuah KTUN.
\end{abstract}

Kata kunci: Asas Presumpto Iustae Causa; KTUN; Pengadilan Tata Usaha Negara.

\begin{abstract}
One of the important principles in administrative law is the principle of Presumptio Iustae Causa which states that the administrative decision must be deemed to betrue according to law. Therefore, it can be carried out as long as it is not proven otherwise by the administrative law judges declaring that it is against the law. By the laws, the administrative law judges are given the authority to declare a delay in the implementation and validity of an administrative decision. A legal question has arisen when the decision no. 53/Pdt.Sus-HKI/Cipta/2017/ PN Jkt.Pst was issued by the District Court. It stated that the Decree of the Minister of Law and Human Rights which was claimed to be the legal standing of the plaintiff must be tested first to review its validity, causing the law suit was not accepted by the Court. The case has pointed out that the District Court's judges have exceeded their authority since it is not their authority to review the validity of an administrative decision.
\end{abstract}

Keywords: Presumptio Iustae Causa Principle; Administrative Decisions; Administrative Court. 


\section{PENDAHULUAN}

Asas Presumptio Iustae Causa atau asas het Vermoden van Rechmatigheid adalah asas yang semula terdapat dalam hukum administrasi dan kemudian dimasukkan sebagai salah satu asas dalam peradilan administrasi. Asas ini menyatakan bahwa demi kepastian hukum, setiap keputusan tata usaha negara yang dikeluarkan harus dianggap benar menurut hukum, karenanya dapat dilaksanakan lebih dahulu selama belum dibuktikan sebaliknya dan dinyatakan oleh hakim administrasi sebagai keputusan yang bersifat melawan hukum. ${ }^{1}$

Asas ini dikuatkan dan dijadikan asas dalam peradilan administrasi, sehingga suatu gugatan yang diajukan pada peradilan administrasi, pada asasnya tidak akan menghalangi dilaksanakannya keputusan badan/pejabat tata usaha negara yang disengketakan. ${ }^{2}$

Namun dalam penerapan asas ini, undang-undang tetap memberi peluang kepada penggugat untuk memohon, agar keputusan tata usaha negara yang disengketakan dapat ditunda pelaksanaannya selama proses pemeriksaan berjalan hingga adanya putusan hakim. Tetapi, permohonan penundaan dapat dikabulkan hanya apabila terdapat keadaan yang sangat mendesak yang mengakibatkan kepentingan penggugat sangat dirugikan jika Keputusan Tata Usaha Negara yang digugat itu tetap dilaksanakan. ${ }^{3}$

Permohonan penundaan dapat diajukan sekaligus dalam gugatan atau dapat pula diajukan secara terpisah, tetapi dalam waktu yang bersamaan dengan diajukannya gugatan atau selambat-lambatnya pada waktu replik diajukan. 4 Kemudian hakim akan memeriksanya dengan acara cepat atau kortgeding. Hakim dapat memberikan putusan penangguhan lebih dahulu dalam bentuk penetapan (schorsing), sebelum pokok perkara diputus. Apabila kemudian putusan akhir menyatakan gugatan ditolak, maka berarti dengan sendirinya penetapan penangguhan tersebut ditolak. ${ }^{5}$

Persoalan muncul ketika Keputusan Tata Usaha Negara yang menjadi legal standing Penggugat (Dewan Pengurus Pusat Asosiasi Pengusaha Komputer Indonesia (DPP APKOMINDO)) dalam perkara 53/Pdt.SusHKI/Cipta/2017/PN Jkt.Pst dinyatakan harus diuji terlebih dahulu keabsahannya. Akibat dari pertimbangan hakim tersebut, maka gugatan Penggugat tidak dapat diterima atau Niet Ontvankelijke Verklaard (NO). Putusan ini sangat merugikan

1 S.F. Marbun, Peradilan Administrasi Negara dan Upaya Administratif di Indonesia (FH UII Press, 2015) 222.

Ibid, 223.

Undang-Undang Republik Indonesia Nomor 5 Tahun 1986 tentang Peradilan Tata Usaha Negara.

Surat Ketua Muda MARI Urusan Lingkungan Peradilan TUN, Nomor 052/Td. TUN/III/1992, Perihal: Juklak yang dirumuskan dalam Pelatihan Peningkatan Keterampilan Hakim Peradilan TUN-III Tahun 1991, tanggal 24 Maret 1992.

5 Setiap tindakan prosesual persidangan dituangkan dalam bentuk Penetapan, kecuali putusan akhir yang harus berkepala putusan; Lihat Surat Edaran Mahkamah Agung RI Nomor 2 Tahun 1991, tentang Petunjuk Pelaksanaan Beberapa Ketentuan dalam Undang- Undang Nomor 5 Tahun 1986 tentang Peradilan Tata Usaha Negara, tanggal 9 Juli 1991. 
Penggugat karena secara tidak langsung hakim telah melakukan penundaan terhadap pelaksanaan Keputusan Tata Usaha Negara. Padahal hakim dalam perkara ini bukanlah hakim adminstrasi yang dapat menyatakan sebuah Keputusan Tata Usaha Negara dapat ditunda pelaksanaannya atau tidak. Yang akan menjadi fokus dalam tulisan ini adalah bagaimanakah penerapan asas presumptio iustae causa dalam keputusan tata usaha negara dan bagaimanakah pertimbangan hakim dalam perkara nomor 53/Pdt.SusHKI/Cipta/2017/PNJkt.Pst sehingga menunda pelaksanaan keputusan tata usaha negara.

\section{PEMBAHASAN}

\section{Keputusan Tata Usaha Negara}

Keputusan Tata Usaha Negara (KTUN) merupakan tindakan hukum publik pemerintah yang bersegi satu atau bersifat sepihak (eenzijdige publiekrechtelijke hendeling). Istilah ini diperkenalkan di Belanda oleh C.W. van der Pot dan C. Van Vollenhoven dengan istilah beschikking dan di Perancis dikenal dengan istilah acte administratif. Istilah beschikking $\mathrm{di}$ Indonesia diperkenalkan oleh WF Prins dan diterjemahkan dengan istilah ketetapan (E. Utrecht, Bagir Manan), penetapan (Prajudi Atmosudirjo), dan keputusan (WF Prins, Philipun Hadjon). ${ }^{6}$

Menurut van der Pot, beschikking adalah tindakan hukum yang dilakukan alat-alat pemerintahan, pernyataan kehendak mereka dalam menyelenggarakan hal khusus, dengan maksud mengadakan perubahan dalam lapangan hubungan hukum. 7 Pasal 1 angka 9 Undang-Undang Nomor 51 Tahun 2009 tentang Perubahan Kedua Atas Undang-Undang Nomor 5 Tahun 1986 tentang Peradilan Tata Usaha Negara menyatakan:

Keputusan Tata Usaha Negara adalah suatu penetapan tertulis yang dikeluarkan oleh badan atau pejabat tata usaha negara yang berisi tindakan hukum tata negara yang berdasarkan peraturan perundang-undangan yang berlaku, yang bersifat konkret, individual, dan final, yang menimbulkan akibat hukum bagi seseorang atau badan hukum perdata.

Sedangkan Pasal 1 angka 7 Undang-Undang Nomor 30 Tahun 2014 tentang Administrasi Pemerintahan menyatakan bahwa:

Keputusan Administrasi Pemerintahan yang disebut Keputusan Tata Usaha Negara atau Keputusan Administrasi Negara yang selanjutnya disebut Keputusan adalah ketetapan tertulis yang dikeluarkan oleh Badan dan/atau Pejabat Pemerintahan dalam Penyelenggaraan Pemerintahan.

Dengan lahirnya Undang-Undang Nomor 30 Tahun 2014 tentang Administrasi Pemerintahan, terjadi perluasan makna KTUN. Pasal 87 Undang-Undang ini menyatakan bahwa KTUN harus dimaknai sebagai:

a. penetapan tertulis yang juga meliputi tindakan faktual;

b. keputusan Badan dan/atau Pejabat Tata Usaha Negara di lingkungan eksekutif, legislatif, yudikatif dan penyelenggara negara lainnya; 
c. berdasarkan ketentuan perundangundangan dan AUPB;

d. bersifat final dalam arti luas;

e. keputusan yang berpotensi menimbulkan akibat hukum; dan/atau

f. keputusan yang berlaku bagi warga masyarakat.

Pada 9 Desember 2016, muncul Surat Edaran Mahkamah Agung (SEMA) Nomor 4 Tahun 2016 tentang Pemberlakuan Rumusan Hasil Rapat Pleno Kamar MA Tahun 2016 Sebagai Pedoman Pelaksanaan Tugas Bagi Pengadilan. SEMA ini mendefinisikan frasa 'final dalam arti luas' yang terdapat dalam Pasal 87 UndangUndang Administrasi Pemerintahan sebagai keputusan yang sudah menimbulkan akibat hukum meskipun masih memerlukan persetujuan dari instansi atasan atau instansi lain. Misalnya, izin lingkungan, dan izin penanaman modal dari Badan Koordinasi Penanaman Modal (BKPM). ${ }^{8}$ Selain itu, KTUN dan/atau tindakan yang berpotensi menimbulkan akibat hukum seperti LHP Badan Pengawas Keuangan dan Pembangunan, juga menjadi objek gugatan/permohonan pada pengadilan tata usaha negara.

Menurut Kuntjoro Purbopranoto, ada dua syarat yang harus dipenuhi agar KTUN yang dibuat oleh pemerintah menjadi keputusan yang sah. Kedua syarat tersebut yakni sebagai berikut: 9

a. syarat materiil, meliputi :
(1) alat pemerintahan yang membuat keputusan harus berwenang (berhak);

(2) dalam kehendak alat pemerintahan yang membuat keputusan tidak boleh ada kekurangan yuridis (geen yuridiche gebreken in de welsvorming);

(3) keputusan harus diberi bentuk (vorm) yang ditetapkan dalam peraturan yang menjadi dasarnya dan pembuatnya harus juga memperhatikan prosedur membuat keputusan bilamana prosedur itu ditetapkan dengan tegas dalam peraturan itu (rechtmatig);

(4) isi dan tujuan keputusan itu harus sesuai dengan isi dan tujuan yang hendak dicapai (doelmatig).

b. syarat formil, meliputi :

(1) syarat-syarat yang ditentukan berhubungan dengan persiapan dibuatnya keputusan dan berhubungan dengan cara dibuatnya keputusan harus dipenuhi;

(2) harus diberi bentuk yang telah ditentukan;

(3) syarat-syarat berhubungan dengan pelaksanaan keputusan itu dipenuhi;

(4) jangka waktu harus ditentukan antara timbulnya hak-hak yang menyebabkan dibuatnya dan diumumkannya keputusan itu dan tidak boleh dilupakan;

(5) ditandatangani oleh pejabat pemerintahan yang berwenang membuat keputusan.

\footnotetext{
8 http://www.hukumonline.com/berita/baca/lt5996d84f8da0d/hakim-perlu-berhati-hatimenerapkan-perluasan-makna-ktum diakses pada 18 April 2018.

9 Sadjijono, Bab-Bab Pokok Hukum Administrasi (LaksBang 2011) 100-101.
} 


\section{Asas Presumptio Iustae Causa}

Asas Presumptio Iustae Causa dianut dalam prinsip umum Pasal 67 ayat (1) Undang-Undang Nomor 5 Tahun 1986 tentang Peradilan Tata Usaha Negara, yang menyebutkan bahwa gugatan tidak menunda atau menghalangi dilaksanakannya Keputusan Badan atau Pejabat Tata Usaha Negara serta tindakan Badan atau Pejabat Tata Usaha Negara yang digugat. Ketentuan ini menimbulkan penafsiran; (1) KTUN selalu harus dianggap menurut hukum atau memiliki legalitas untuk dilaksanakan sejauh belum ada putusan Pengadilan yang inkracht van gewijsde mengenai harus dinyatakan batal atau tidak sahnya Keputusan (beschikking) tersebut. Proses di muka Pengadilan Tata Usaha Negara memang dimaksudkan untuk menguji (toetsing) apakah dugaan bahwa KTUN yang digugat itu melawan hukum beralasan atau tidak; (2) Seharusnya, KTUN sudah merupakan bentuk atau manifestasi tindakan pemerintahan dan Badan atau Pejabat Tata Usaha Negara. Namun, dari ketentuan Pasal 67 ayat (1) tersebut, antara KTUN dengan tindakan Badan atau Pejabat Tata Usaha Negara dibedakan dengan penambahan kata "serta" di antara keduanya. ${ }^{10}$

Suatu KTUN atau tindakan hukum administrasi itu selalu diduga sah menurut hukum dan karenanya selalu dapat dilaksanakan seketika. Jadi, suatu keputusan administratif itu dianggap berdiri segaris dengan suatu putusan pengadilan atau suatu akta otentik. Walaupun keputusan yang bersangkutan itu digugat, hal itu tidak menghalangi bekerjanya prinsip tersebut. ${ }^{11}$

Pasal 67 ayat (2) Undang-Undang Nomor 5 Tahun 1986 tentang Peradilan Tata Usaha Negara memberi hak kepada penggugat untuk "dalam keadaan tertentu" (Pasal 67 ayat (4) sub a) diperkenankan menyimpangi asas Presumptio Iusate Causa yang terdapat pada Pasal 67 ayat (1). Kriteria penundaan pelaksanaan KTUN di dalam undang-undang hanya disebutkan harus terdapar keadaan yang sangat mendesak yang mengakibatkan kepentingan penggugat sangat dirugikan jika KTUN yang digugat itu tetap dilaksanakan. Pengertian istilah "keadaan yang sangat mendesak" di dalam Pasal 67 tersebut dijelaskan yaitu jika kerugian yang akan diderita penggugat akan sangat tidak seimbang dibanding manfaat bagi kepentingan yang akan dilindungi oleh pelaksanaan KTUN tersebut. Oleh karena itu, untuk menilai adanya "keadaan yang sangat mendesak" harus dilihat secara kasuistis berdasarkan fakta konkret yang terjadi dan kemungkinan kerugian yang akan timbul harus dinilai secara obyektif. ${ }^{12}$

Kata mendesak terjadi apabila ada perubahan-perubahan baik faktual maupun secara ekonomi, yang sulit atau tidak mungkin dikembalikan lagi kepada keadaan semula, apabila KTUN

10 W. Riawan Tjandra, Hukum Acara Peradilan Tata Usaha Negara (UAJY 2005) 77-78.

11 Indroharto, Upaya Memahami Undang-Undang Tentang Peradilan Tata Usaha Negara (Pustaka Sinar Harapan 1991) 333.

12 W. Riawan Tjandra, Op. Cit,78-79. 
tersebut dilaksanakan. Tidak terdapat keadaan mendesak apabilan dengan dilaksanakannya KTUN tersebut tidak terjadi perubahan faktual dan ekonomi yang drastis ${ }^{13}$, atau sekalipun terjadi perubahan-perubahan, perubahan tersebut bergerak lambat, seimbang dengan irama proses pemeriksaan persidangan, misalnya sertifikat tanah apabila tidak ada tanda-tanda akan diperjualbelikan atau dijadikan hak tanggungan, maka dalam hal ini tidak ada keadaan yang mendesak. ${ }^{14}$

Di dalam Pasal 67 ayat (4) sub b Undang-Undang Nomor 5 Tahun 1986 maupun di dalam penjelasannya, dikatakan bahwa permohonan penundaan tidak dapat dikabulkan apabila kepentingan umum dalam rangka pembangunan mengharuskan dilaksanakannya keputusan tersebut. ${ }^{15}$ Jika semua jenis kegiatan pembangunan yang dilakukan berdasarkan persyaratan-persyaratan yang disebutkan dalam RUTR mengandung unsur kepentingan umum dalam rangka pembangunan maka permohonan penundaan harus ditolak. 16

Berdasarkan ketentuan yang telah dijabarkan sebelumnya, Penulis berpendapat bahwa gugatan untuk melakukan penundaan KTUN merupakan hak dari penggugat yang merasa kepentingannya dirugikan. Jika penundaan pelaksanaan KTUN tidak dimohonkan oleh penggugat, maka hakim tidak memiliki kewenangan untuk memutus penundaan pelaksanaan KTUN.

Menurut Indroharto, terdapat ukuran atau faktor-faktor yang perlu diperhatikan untuk mengabulkan atau menolak permohonan penundaan pelaksanaan KTUN yang digugat yakni: ${ }^{17}$

1. Harus dilakukan pertimbanganpertimbangan mengenai kepentingan-kepentingan yang tersangkut. Pertimbangan itu meliputi:

- Kepentingan umum

- Kepentingan penggugat

- Kepentingan pihak ketiga yang berkaitan

- Perbandingan bobot kepentingan penggugat dan kepentingan umum untuk mana keputusan itu dikeluarkan

- Urgensi sebagai akibat kemungkinan timbulnya kerugian.

2. Sempurna/tidaknya permohonan yang bersangkutan. Berkaitan dengan kejelasan gugatan dan kelengkapan alasan permohonan.

3. Sikap penggugat dalam menemukan fakta-fakta. Permohonan harus mencerminkan kesungguhan dan keseriusan penggugat dalam membantu

13 Penundaan pelaksanaan KTUN menjadi penting dalam beberapa kasus karena jika tidak justru akan merugikan pemerintah. Misal dalam kasus Hotel Mulia yang sebagian lahannya digunakan oleh pemerintah, namun ternyata tindakan pemerintah itu tidak tepat dan dianggap OOD (Onrechmatige Overheid Daad) sehingga pemerintah harus mengganti rugi ke Hotel Mulia.

14 Lintong O. Siahaan, Berbagai Instrumen Hukum di PTUN (Percetakan Percetakan Negara RI 2007$) 112$.

15 Lintong O. Siahaan, Eksekusi Putusan di Peradilan Tata Usaha Negara Setelah Amandemen, Sistem Peradilan Dua Tingkat di PTUN dan Putusan Penundaan (Percetakan Negara RI 2007) 53.

16 Ibid; 61.

17 Indroharto, Op. Cit., 214-215. 
Pengadilan dalam menemukan fakta-fakta sehubungan sengketa yang timbul.

4. Kepentingan penggugat yang sangat mendesak. Harus terbukti adanya keadaan yang mendesak bagi penggugat karena keputusan yang bersangkutan itu akan segera dilaksanakan.

5. Penilaian sementara mengenai pokok perkara. Penilaian ini mengenai kemungkinan dasar pengujian yang dapat diterapkan terhadap gugatan pokok sehubungan kejelasan gugatan pokok (namun belum terikat pada dasar pengujian Pasal 53 ayat (2), karena belum dilakukan pengujian).

Terdapat kemungkinan pihak ketiga mengajukan permohonan penundaan pelaksanaan KTUN ialah apabila pihak ketiga bertindak sebagai intervenient, yang mewakili kepentingannya sendiri (penggugat) dan kepentingan itu paralel dengan kepentingan penggugat semula. 18

Putusan penundaan sangat berpengaruh terhadap tugas pelayanan pemerintah kepada masyarakat atau dengan perkataan lain dapat menghambat program-program pembangunan yang sedang dicanangkan. Hal-hal tersebut akan berakibat terhadap investasi dan perekonomian, yang pada akhirnya dapat berpengaruh terhadap kehidupan masyarakat. Oleh karena itu, penjatuhan putusan penundaan tersebut harus dilakukan benar-benar sesuai dengan hukum, dan dalam rangka kontrol yuridis terhadap pemerintah (penguasa), sehingga sasaran utamanya adalah tetap pada kepentingan masyarakat (welfare state), bukan malah sebaliknya. 19

\section{SK MenkumHAM RI Nomor AHU- 000478.AH.01.08. Tahun 2017 Sebagai KTUN}

Perkara nomor 53/Pdt.SusHKI/Cipta/2017/PN Jkt.Pst bermula dengan adanya gugatan dari Dewan Pengurus Pusat Asosiasi Pengusaha Komputer Indonesia (DPP APKOMINDO) dengan Tergugat I Sonny Franslay dan Tergugat II Pemerintah RI cq Menteri Hukum dan HAM RI cq Dirjen HKI cq Direktur Hak Cipta dan Desain Industri. Dalam petitum gugatannya, Penggugat memohon pada majelis hakim:20

1. Mengabulkan Gugatan Penggugat untuk seluruhnya ;

2. Menyatakan Pencatatan Ciptaan tidak dapat dilakukan terhadap Seni Logo "APKOMINDO" ;

3. Membatalkan atau setidak-tidaknya menyatakan batal Surat Pendaftaran Ciptaan Nomor 050083 tertanggal 9 Maret 2011 dengan Nomor Permohonan C00201004539 tertanggal 27 Desember 2010 terhadap Seni Logo "APKOMINDO" atas nama SONNY FRANSLAY dalam Daftar Umum Ciptaan yang terdapat pada Tergugat II;

4. Memerintahkan Tergugat II untuk mencatat pembatalan dan mencoret Surat Pendaftaran Ciptaan Nomor

18 W. Riawan Tjandra, Op. Cit, 80.

19 Lintong O. Siahaan, Prospek PTUN Sebagai Pranata Penyelesaian Sengketa Administrasi Indonesia (Percetakan Negara RI 2005) 207.

20 http://sipp.pn-jakartapusat.go.id/index.php/detil_perkara diakses pada 25 Maret 2018. 
050083 tertanggal 9 Maret 2011 dengan Nomor Permohonan C00201004539 tertanggal 27 Desember 2010 terhadap Seni Logo "APKOMINDO" atas nama SONNY FRANSLAY dari dalam Buku Daftar Umum Ciptaan yang terdapat pada Tergugat II;

5. Menyatakan Penggugat memiliki hak untuk menggunakan Seni Logo "APKOMINDO" selama perkumpulan APKOMINDO masih berdiri tanpa memerlukan ijin dari Tergugat I;

6. Menyatakan Penggugat sebagai Pemegang Hak Cipta atas Seni Logo "APKOMINDO";

7. Memerintahkan Tergugat II untuk memproses permohonan dan pendaftaran Seni Logo "APKOMINDO" oleh Penggugat ke atas nama Penggugat;

8. Menghukum Tergugat I untuk membayar biaya perkara;

i. ATAU

ii. Mohon putusan yang seadiladilnya. (exaequo et bono).

Legal Standing Penggugat (Dewan Pengurus Pusat Asosiasi Pengusaha Komputer Indonesia) adalah SK MenkumHAM RI Nomor AHU000478.AH.01.08.Tahun 2017. Dalam SK tersebut, tercatat sebagai Ketua Umum adalah Ir. Soegiharto Santoso dan Ir. Muzakkir sebagai Sekretaris Jenderal.

Penulis hendak memberikan analisis terlebih dahulu terhadap SK MenkumHAM RI Nomor AHU -
000478.AH.01.08.Tahun 2017. Menurut Penulis, SK MenkumHAM RI Nomor AHU -000478.AH.01.08.Tahun 2017 adalah Keputusan Tata Usaha Negara. Kesimpulan ini berdasarkan unsur-unsur yuridis keputusan menurut hukum positif, yaitu:21

a. Suatu penetapan tertulis;

b. Dikeluarkan oleh badan atau pejabat tata usaha negara;

c. Berisi tindakan hukum tata usaha negara;

d. Berdasarkan peraturan perundangundangan yang berlaku;

e. Bersifat konkrit, individual dan final;

f. Menimbulkan akibat hukum bagi seseorang atau Badan Hukum Perdata.

Penetapan tertulis merupakan tolok ukur pangkal sengketa dalam peradilan administrasi atau merupakan kompetensi absolut peradilan administrasi atau juga merupakan tolak ukur horizontal Badan Peradilan Administrasi Nasional. Penetapan tertulis bukanlah ditujukan kepada bentuk formalnya suatu surat keputusan, tetapi menunjuk kepada isinya. 22 Dalam konteks SK MenkumHAM RI Nomor AHU000478.AH.01.08.Tahun 2017, jelas bahwa SK tersebut adalah sebuah penetapan tertulis.

Menurut Pasal 1 angka 8 UndangUndang Nomor 51 Tahun 2009 tentang Perubahan Kedua Atas Undang-Undang Nomor 5 Tahun 1986 tentang Peradilan Tata Usaha Negara, "Badan atau Pejabat Tata Usaha Negara adalah badan atau

${ }^{21}$ S.F. Marbun, 'Telaah Yurisprudensi Aanwijziq Natuurmonumenten, Penunjukkan Satu Daerah Sebagai Staatnatuurmonument Bukan Merupakan Keputusan yang Mengikat Umum' (Penataran Hukum Administrasi Negara, Bandung, Agustus 1987).

22 S.F. Marbun, Op. Cit, 162-163. 
pejabat yang melaksanakan urusan pemerintahan berdasarkan peraturan perundang-undangan

yang

berlaku. 'Pengertian menyelenggarakan urusan pemerintahan dalam arti luas, berarti juga menyelenggarakan fungsi pembuatan undang-undang dan fungsi peradilan, sedangkan pengertian menyelenggarakan urusan pemerintahan dalam arti sempit, berarti kegiatan yang hanya bersifat eksekutif baik di pusat maupun di daerah. Dengan demikian yang dimaksud dengan Badan/Pejabat Tata Usaha Negara adalah mereka yang menyelenggarakan suatu urusan pemerintahan atau eksekutif atau yang menyelenggarakan fungsi atau tugas pemerintahan. Menteri Hukum dan HAM RI termasuk ke dalam lingkungan eksekutif. ${ }^{23}$ Sehingga Keputusan yang dikeluarkannya adalah Keputusan Tata Usaha Negara.

Tindakan hukum dibedakan antara tindakan hukum privat dan tindakan hukum publik. Kemudian dilihat dari pihak yang akan terkena tindakan tersebut, tindakan hukum publik dapat pula dibedakan antara berbagai pihak dan sepihak, sedangkan tindakan hukum sepihak dapat bersifat umumabstrak dan bersifat konkrit-individual. Setiap tindakan hukum tata usaha negara akan melahirkan akibat hukum dan hubungan hukum antara badan/pejabat tata usaha negara dengan warga masyarakat. Salah satu bentuk tindakan hukum tersebut ialah keputusan yang bersifat konkrit, individual dan final. Terdapat pengecualian menurut Pasal 2 beserta penjelasan Undang-Undang Nomor 5 Tahun 1986 tentang Peradilan Tata Usaha Negara yang memuat beberapa tindakan badan/pejabat tata usaha negara yang tidak termasuk dalam pengertian KTUN. ${ }^{24}$ Menurut Penulis, SK MenkumHAM RI Nomor AHU000478.AH.01.08.Tahun 2017 tidak termasuk dalam Pasal 2 beserta penjelasan Undang-Undang Nomor 5 Tahun 1986 tentang Peradilan Tata Usaha Negara, sehingga merupakan KTUN

Berdasarkan peraturan perundangundangan yang berlaku berkaitan dengan salah satu prinsip hukum atau asas legalitas, sebab Administrasi Negara dalam pengertian yuridis adalah pelaksana atau penyelenggara dari undang-undang dalam arti luas (wet in ruine zin). Badan/pejabat tata usaha negara yang tanpa dasar kewenangan peraturan umum atau atribusi, tidak mempunyai wewenang untuk melakukan suatu perbuatan hukum publik. ${ }^{25}$ Dirjen Administrasi Hukum Umum atas nama Menteri Hukum dan HAM RI memiliki hak dan kewenangan untuk memberikan pengesahan badan hukum APKOMINDO, sehingga SK MenkumHAM RI Nomor AHU000478.AH.01.08.Tahun 2017 termasuk dalam KTUN.

Bersifat konkrit, individual dan final. Konkrit yaitu obyek yang diputuskan dalam KTUN itu tidak abstrak tetapi berwujud, tertentu atau dapat ditentukan. Dalam hal apa dan kepada siapa KTUN itu dikeluarkan, harus 
secara jelas disebutkan dalam keputusan atau obyek dan subyeknya harus disebutkan secara tegas dan jelas dalam keputusan itu. Individual artinya KTUN itu tidak ditujukan untuk umum, tetapi tertentu baik alamat maupun hal yang dituju. Jika yang dituju lebih dari seorang maka tiap-tiap orang yang terkena keputusan harus disebutkan namanya satu persatu. Final artinya keputusan tersebut setelah bersifat definitif, sehingga mempunyai akibat hukum tertentu. Keputusan yang belum definitif karena masih memerlukan persetujuan dari instansi atasan atau instansi lainnya belum dikatakan bersifat final, sehingga belum menimbulkan hak dan kewajiban bagi yang terkena keputusan tersebut. 26 Menurut Penulis, SK MenkumHAM RI Nomor AHU-000478.AH.01.08.Tahun 2017 bersifat konkrit karena menyebutkan obyek dan subyek secara tegas dan jelas. Bersifat individual karena nama-nama pengurus dan pengawas disebutkan satu per satu dalam SK tersebut. Bersifat final karena SK ini tidak memerlukan persetujuan dari instansi atasan atau instansi lainnya.

Badan hukum sebagai subjek hukum sama halnya dengan manusia, mempunyai hak dan kewajiban sehingga dapat mengadakan hubunganhubungan hukum. Menurut Kitab Undang-Undang Hukum Perdata, Perkumpulan merupakan badan hukum yang diakui oleh pemerintahan/kekuasaan umum. 27 Menurut Penulis, SK MenkumHAM RI Nomor AHU-000478.AH.01.08.Tahun
2017 telah menimbulkan akibat hukum bagi APKOMINDO untuk dapat mengadakan hubungan hukum.

Berdasarkan unsur-unsur yuridis yang telah disebutkan dan dijabarkan oleh Penulis, maka Penulis berkesimpulan bahwa SK MenkumHAM RI Nomor AHU-000478.AH.01.08.Tahun 2017 merupakan KTUN karena telah memenuhi unsur-unsur suatu penetapan tertulis; dikeluarkan oleh badan atau pejabat tata usaha negara; berisi tindakan hukum tata usaha negara; Berdasarkan peraturan perundang-undangan yang berlaku; bersifat konkrit, individual dan final; dan menimbulkan akibat hukum bagi seseorang atau Badan Hukum Perdata.

Jika seseorang/badan hukum hendak memohon penundaan pelaksanaan KTUN, maka harus mengajukan gugatan ke Pengadilan Tata Usaha Negara. Menurut Pasal 1 angka 11 Undang-Undang Nomor 51 Tahun 2009 tentang Perubahan Kedua Atas Undang-Undang Nomor 5 Tahun 1986 tentang Peradilan Tata Usaha Negara, "Gugatan adalah permohonan yang berisi tuntutan terhadap badan atau pejabat tata usaha negara dan diajukan ke pengadilan untuk mendapatkan putusan." Merujuk Pasal 1 angka 1 Undang-Undang Nomor 51 Tahun 2009 tentang Perubahan Kedua Atas Undang-Undang Nomor 5 Tahun 1986 tentang Peradilan Tata Usaha Negara, Pengadilan yang dimaksud dalam ketentuan di atas adalah Pengadilan Tata Usaha Negara.

Sebagian besar, bahkan hampir seluruhnya putusan penundaan (99\%)

\footnotetext{
26 Ibid, 175.

27 Ibid, 176-177.
} 
dilakukan oleh Ketua PTUN sebelum perkara dilimpahkan kepada majelis hakim. Begitu perkara gugatan masuk (diregister), pada saat itu juga Ketua PTUN dapat mengeluarkan putusan penundaan. Hanya merupakan pengecualian-pengecualian saja, atau dalam hal-hal tertentu dilakukan oleh Majelis Hakim. Hal ini terjadi karena, pada umumnya gugatan yang ditujukan kepada pihak pemerintah tersebut adalah perbuatan-perbuatan yang apabila dilaksanakan langsung menimbulkan akibat (kerugian) bagi penggugat. 28

Undang-undang tidak mengatur apakah PTTUN dan Mahkamah Agung berwenang melakukan putusan penundaan. Oleh karena tidak diatur, secara teoritis hal itu mungkin saja dapat dilakukan, apabila masalah tersebut muncul pada kedua tingkat pemeriksaan tersebut. dalam praktik hingga saat ini masalah tersebut belum pernah muncul, akan tetapi secara teoritis selama proses pemeriksaan persidangan berlangsung, apabila hal itu menjadi masalah, maka baik peradilan banding, maupun peradilan kasasi harus mempertimbangkannya dan memberikan putusan. ${ }^{29}$

\section{Ketidakcermatan Hakim Memutus Perkara}

Dalam pertimbangan Putusan Nomor 53/Pdt.Sus-HKI/Cipta/2017/ PN Jkt.Pst, majelis hakim berpendapat:

“...kepengurusan Soegiharto Santoso (Penggugat) maupun kepengurusan
Rudi D. Muliadi 30 belum dapat dipandang sebagai pengurus pusat APKOMINDO yang sah menurut hukum, yang oleh karenanya dapat bertindak untuk dan atas nama APKOMINDO. Hal mana harus terlebih dahulu memperoleh pengukuhan berdasarkan putusan pengadilan yang telah berkekuatan hukum tetap. Menimbang bahwa oleh karena Penggugat in casu Soegiharto dan Muzakkir belum dapat dikualifisir sebagai pengurus APKOMINDO yang sah maka Penggugat tidak punya hak dan tidak punya kualitas untuk mengajukan gugatan dalam perkara ini, untuk dan atas nama DPP APKOMINDO."

Pertimbangan majelis hakim ini berakibat putusan dalam pokok perkara menyatakan gugatan Penggugat tidak dapat diterima dan menghukum Penggugat untuk membayar seluruh biaya yang timbul dari perkara ini.

Menurut Penulis, hal ini merupakan ketidakcermatan hakim dalam mengadili dan memutus perkara ini. Bagaimana mungkin seorang hakim peradilan umum menegasikan SK MenkumHAM RI Nomor AHU000478.AH.01.08.Tahun 2017. Ada beberapa hal yang perlu dikritisi dari pertimbangan dan putusan hakim. Pertama, hakim pada peradilan umum tidak memiliki kewenangan untuk menyatakan sah atau tidaknya suatu KTUN. Dengan mengatakan, "harus terlebih dahulu memperoleh pengukuhan berdasarkan putusan pengadilan yang telah berkekuatan hukum tetap" maka secara implisit hakim telah melakukan penundaan pelaksanaan KTUN. Jika demikian, maka seluruh SK yang

\footnotetext{
28 Lintong O. Siahaan, Op. Cit., 225.

29 Ibid., 228.

30 Rudi D. Muliadi adalah saksi Tergugat 1 yang merupakan Ketua APKOMINDO DKI Jakarta dengan SK MenkumHAM RI Nomor AHU-0000058.AH.01.08.Tahun 2017.
} 
dikeluarkan oleh Menteri Hukum dan HAM harus memperoleh pengukuhan berdasarkan putusan pengadilan yang telah berkekuatan hukum tetap agar dapat dilaksanakan. Kedua, alasan hakim yang menyatakan terdapat dua kepengurusan APKOMINDO tidak dapat dibenarkan karena SK MenkumHAM RI Nomor AHU-000478.AH.01.08.Tahun 2017 adalah untuk Pengesahan Pendirian Badan Hukum Perkumpulan Pengusaha Komputer Indonesia disingkat APKOMINDO. Sedangkan SK MenkumHAM RI Nomor AHU0000058.AH.01.08.Tahun 2017 adalah untuk Pengesahan Pendirian Badan Hukum Perkumpulan Pengusaha Komputer Indonesia DKI Jakarta disingkat APKOMINDO DKI Jakarta. Jika penggugat bertindak untuk dan atas nama APKOMINDO, maka jelas dasar legal standing nya adalah SK MenkumHAM RI Nomor AHU 000478.AH.01.08.Tahun 2017. Ketiga, tidak ada pihak yang memohon penundaan pelaksanaan SK MenkumHAM RI Nomor AHU000478.AH.01.08.Tahun 2017.

Putusan ini telah merugikan APKOMINDO karena secara tidak langsung hakim tidak menganggap eksistensi/keberadaannya sebagai badan hukum yang sah. Penulis berpendapat, APKOMINDO dapat melakukan upaya hukum kasasi.

\section{PENUTUP}

Asas Presumptio Iustae Causa menyatakan bahwa demi kepastian hukum, setiap keputusan tata usaha negara yang dikeluarkan harus dianggap benar menurut hukum, karenanya dapat dilaksanakan lebih dahulu selama belum dibuktikan sebaliknya dan dinyatakan oleh hakim administrasi sebagai keputusan yang bersifat melawan hukum. SK MenkumHAM RI Nomor AHU000478.AH.01.08.Tahun 2017 adalah KTUN karena telah memenuhi unsurunsur yuridis yang ada dalam hukum positif. SK ini tetap berlaku sampai ada keputusan yang menyatakan sebaliknya. Dengan demikian, Hakim pada peradilan umum tidak memiliki kewenangan untuk menyatakan suatu keputusan (beschikking) ditunda pelaksanaannya atau bahkan menyatakan tidak sah.

Saran Penulis, APKOMINDO dapat melakukan upaya hukum kasasi untuk memperoleh keadilan. Selain itu, perlu dilakukan evaluasi terhadap kinerja majelis hakim yang memutus perkara ini terlebih pada pemahaman asas Presumptio Iustae Causa dalam tataran penerapan di proses peradilan.

\section{DAFTAR BACAAN}

\section{Buku}

Indroharto, Upaya Memahami UndangUndang Tentang Peradilan Tata Usaha Negara (Pustaka Sinar Harapan 1991).

Koesoemahatmadja, Djenal Hoesen, Pokok-Pokok Hukum Tata Usaha Negara (Alumni 1983).

Marbun, S.F, Peradilan Administrasi Negara dan Upaya Administratif di Indonesia (FH UII Press 2015).

Ridwan, HR, Hukum Administrasi Negara (Rajagrafindo Persada 2006).

Sadjijono, Bab-Bab Pokok Hukum Administrasi (LaksBang 2011). 
Siahaan, Lintong O, Berbagai Instrumen Hukum di PTUN (Percetakan Percetakan Negara RI 2007).

L Eksekusi Putusan di Peradilan Tata Usaha Negara Setelah Amandemen, Sistem Peradilan Dua Tingkat di PTUN dan Putusan Penundaan (Percetakan Negara RI 2007).

Pranata Penyelesaian Sengketa
Administrasi Indonesia (Percetakan
Negara RI 2005).
Tjandra, W. Riawan, Hukum Acara
Peradilan Tata Usaha Negara (UAJY
2005).

\section{Makalah Seminar}

Marbun, S.F, 'Telaah Yurisprudensi Aanwijziq Natuurmonumenten, Penunjukkan Satu Daerah Sebagai Staatnatuurmonument Bukan Merupakan Keputusan yang Mengikat Umum' (Bandung, 10-22 Agustus 1987).

\section{Peraturan Perundang-Undangan}

Undang-Undang Republik Indonesia Nomor 5 Tahun 1986 tentang Peradilan Tata Usaha Negara.

Undang-Undang Republik Indonesia Nomor 51 Tahun 2009 tentang Perubahan Kedua Atas UndangUndang Nomor 5 Tahun 1986 tentang Peradilan Tata Usaha Negara.

Undang-Undang Republik Indonesia Nomor 30 Tahun 2014 tentang Administrasi Pemerintahan.

\section{Putusan Pengadilan}

Sonny Franslay vs. Menteri Hukum dan Hak Asasi Manusia Republik Indonesia, Asosiasi Pengusaha
Komputer Indonesia, No. 483/K/TUN/2016, Mahkamah Agung Republik Indonesia, 1 Desember 2016.

\section{Surat Edaran}

Surat Edaran Mahkamah Agung Nomor 4 Tahun 2016 tentang Pemberlakuan Rumusan Hasil Rapat Pleno Kamar MA Tahun 2016 Sebagai Pedoman Pelaksanaan Tugas Bagi Pengadilan.

\section{Internet}

http:// sipp.pn-jakartapusat.go.id/ind ex.php/detil_perkara diakses pada 25 Maret 2018.

http://www.hukumonline.com/berita/ baca/1t5996d84f8da0d/hakimperlu-berhati-hati-menerapkanperluasan-makna-ktun diakses pada 18 April 2018. 
